\title{
Faktor-Faktor yang Mempengaruhi Persistensi Laba (Studi Kasus Pada Perusahaan Perbankan dan Jasa Keuangan yang Terdaftar di Bursa Efek Indonesia)
}

\author{
Riana Syintia Rahesti, Ahmad Basid Hasibuan* \\ Program Studi Akuntansi Fakultas Ekonomi, Universistas Darma Persada, Jakarta, Indonesia \\ Email: ${ }^{1}$ syintia995@gmail.com, 2,*basid_unsada@yahoo.co.id \\ Email Penulis Korespondensi: basid_unsada@yahoo.co.id \\ Submitted: 17/11/2021; Accepted: 27/11/2021; Published: 30/11/2021
}

\begin{abstract}
Abstrak-Penelitian ini bertujuan untuk menguji faktor-faktor yang mempengaruhi persistensi laba pada perusahaan perbankan dan jasa keuangan yang terdaftar di Bursa Efek Indonesia (BEI) periode 2014-2018. Penelitian ini menggunakan metode kuantitatif dengan purposive sampling. Ada 33 perusahaan sampel dengan total 165 observasi. Analisis data dalam penelitian ini menggunakan uji asumsi klasik dan pengujian hipotesis menggunakan metode regresi linier berganda. Hasil penelitian menunjukkan bahwa perbedaan temporer berpengaruh positif dan signifikan terhadap persistensi laba. Perbedaan permanen berpengaruh negatif dan signifikan terhadap persistensi laba. Arus kas operasi berpengaruh positif dan signifikan terhadap persistensi laba. Sedangkan variabel bebas mampu menjelaskan variabel terikat 54,7\%, sedangkan sisanya dijelaskan oleh variabel lain di luar variabel penelitian ini.
\end{abstract}

Kata Kunci: Perbedaan Sementara; Perbedaan Permanen; Arus Kas Operasi; Persistensi Penghasilan

\begin{abstract}
This study aims to examine the factors that influence earnings persistence on banking and financial service companies listed on the Indonesia Stock Exchange (IDX) period 2014-2018. This research uses quantitative methods with purposive sampling. There are 33 sample companies with a total of 165 observations. Data analysis in this study uses the classic assumption test and hypothesis testing using multiple linear regression methods. The results showed that temporary differences had a positive and significant effect on earnings persistence. Permanent differences have a negative and significant effect on earnings persistence. Operating cash flow has a positive and significant effect on earnings persistence. While the independent variable is able to explain the dependent variable $54.7 \%$, while the rest is explained by other variables outside this research variable.
\end{abstract}

Keyword: Temporary Differences; Permanen Differences; Operating Cash Flow; Earnings Persistences

\section{PENDAHULUAN}

Laba merupakan komponen penting yang menjadi pusat perhatian dalam laporan keuangan. Karena angka yang menunjukkan laba usaha dapat digunakan sebagai dasar untuk mengevaluasi kinerja keuangan perusahaan baik internal maupun eksternal. Laba (earnings) pada dasarnya harus menunjukkan informasi keuangan yang benar, karena earnings dipandang sebagai indikator sukses atau gagalnya manajemen dalam mencapai tujuan perusahaan (Magfiroh \& Kusmuriyanto, 2018).

Laba selalu dijadikan dasar untuk memberikan kompensasi, pembagian bonus kepada manajer, pengukur prestasi atau kinerja manajemen, dan sebagai dasar penentuan pajak. Dengan demikian, laba menjadi pusat perhatian sekaligus memberikan sebuah sinyal tentang nilai perusahaan bagi investor, kreditor, pembuat kebijakan akuntansi dan pemerintah (Brolin \& Rohman, 2014). Laba yang tinggi akan menimbulkan penilaian pasar dan pengembalian yang lebih tinggi. Perusahaan dengan pendapatan berkualitas tinggi akan menikmati harga saham yang lebih tinggi begitupun sebaliknya. laba yang tidak persisten akan menimbulkan masalah yaitu ketidaktepatan dalam alokasi sumber daya dan pengambilan keputusan yang didasarkan pada kondisi di masa mendatang. Selain itu dapat menurunkan kepercayaan investor karena resiko investasi yang tinggi. Sehingga investor akan mengalami kesulitan dalam menilai kinerja perusahaan dan membuat keputusan investasi yang rasional (Waluyo, 2016).

Laporan keuangan disusun untuk dua tujuan setiap tahunnya yaitu berdasarkan prinsip akuntansi yang berlaku umum, dan laporan keuangan untuk pelaporan pajak berdasarkan peraturan perpajakan untuk menentukan besarnya penghasilan kena pajak atau laba fiskal. Salah satu isu yang berkembang mengenai analisis peraturan perpajakan yang menarik banyak perhatian yaitu book tax difference (Dewi \& Asri, 2015). Book tax difference merupakan perbedaan antara perhitungan laba akuntansi dan laba fiskal akibat rekonsiliasi fiskal. Ikatan Akuntan Indonesia (IAI) menerbitkan Pernyataan Standar Akuntansi Keuangan (PSAK) No. 46 yang mengatur tentang akuntansi pajak penghasilan yang wajib diberlakukan untuk pelaporan keuangan. Manajemen memiliki kebebasan dalam menentukan kebijakan akuntansi serta besaran pencadangan beban/ penghasilan pajak tangguhan.

Perbedaan penghasilan dan biaya/ pengeluaran menurut akuntansi dan menurut fiskal dapat dikelompokkan menjadi perbedaan tetap atau perbedaan permanen (permanent differences) dan perbedaan sementara atau perbedaan waktu/ timing differences (Resmi, 2014:403). Perbedaan temporer terjadi karena perbedaan waktu pengakuan pendapatan dan biaya dalam menghitung laba. Perbedaan temporer menyebabkan laba fiskal bertambah atau berkurang pada periode yang akan datang. Sedangkan, perbedaan permanen terjadi karena transaksi-transaksi pendapatan dan biaya diakui menurut akuntansi dan tidak diakui menurut fiskal atau sebaliknya. Perbedaan permanen mengakibatkan laba (rugi) bersih menurut akuntansi berbeda (secara tetap) dengan penghasilan laba kena pajak menurut fiskal.

Beberapa penelitian membuktikan bahwa perbedaan temporer memiliki hubungan negatif dengan persistensi laba adalah Martinez et al., (2013); Addeh, (2016); Waluyo, (2016); Praptitorini \& Rahmawati, (2017); Ariyani \& 
Wulandari, (2017); Adiati, Rahmawati \& Bandi, (2018). Hasil ini konsisten dengan penelitian yang dilakukan oleh Jackson (2015). Dimana pada tahun 2015, Jackson dalam penelitiannya menghasilkan hubungan signifikan negatif secara statistik terhadap perubahan beban pajak.

Penelitian ini bertentangan dengan Racca, (2011); Ahnan \& Murwaningsari, (2019) yang menghasilkan pengaruh positif tidak signifikan antara perbedaan temporer dengan persistensi laba. Sedangkan Dillak et al,. (2017) membuktikan bahwa perbedaan temporer tidak berpengaruh terhadap persistensi laba. Perbedaan temporer mengakibatkan pergeseran pengakuan penghasilan dan biaya antara satu tahun pajak ke tahun pajak lainnya, sehingga mengakibatkan besarnya laba fiskal menjadi lebih tinggi dari pada laba akuntansi atau sebaliknya.

Selanjutnya, hasil penelitian Martinez et al., (2013); Dewi \& Putri, (2015); Addeh, (2016); Waluyo, (2016); Ahnan \& Murwaningsari, (2019) membuktikan bahwa terdapat hubungan positif antara perbedaan permanen dengan persistensi laba. Hasil penelitian ini menunjukan bahwa perbedaan permanen bisa menjadi sinyal atas kualitas laba. Perbedaan permanen yang tetap dari tahun ke tahunnya akan menyebabkan laba yang lebih persisten. Hal ini disebabkan karena hal yang pasti atas beban pajak kini yang akan terjadi di masa yang akan datang menyebabkan laba yang diharapkan di masa yang akan datang menjadi pasti juga.

Penelitian ini bertentangan dengan Praptitorini \& Rahmawati, (2017); Ariyani \& Wulandari, (2017); Dillak et al., (2017) yang menghasilkan hubungan negatif antara perbedaan permanen dengan persistensi laba. Jackson, (2015) memasukkan manajemen laba sebagai variabel moderating dan membuktikan bahwa terdapat hubungan negatif antara perbedaan permanen dengan persistensi laba. Adanya perbedaan hasil penelitian ini membuat variabel tersebut menarik untuk diteliti kembali.

Faktor lain yang mempengaruhi persistensi laba yaitu arus kas operasional (operating cash flow) yang terkandung dalam laba saat ini yang mewakili sifat transitory dan laba pemanen. Laporan arus kas merupakan salah satu laporan keuangan pokok, disamping neraca dan laporan laba rugi. Laporan laba rugi suatu perusahaan dapat memberikan gambaran bahwa perusahaan tersebut mendapatkan keuntungan yang tinggi. Namun, nilai yang terkandung didalam arus kas atau aliran kas pada suatu periode mencerminkan nilai laba dalam metode kas (cash basis). Data arus kas merupakan indikator keuangan yang lebih baik dibandingkan dengan akuntansi karena arus kas relatif lebih sulit untuk dimanipulasi. Arus kas dari aktivitas operasi terutama diperoleh dari aktivitas penghasil utama pendapatan perusahaan sehingga semakin tingginya aliran kas operasi terhadap laba, maka akan semakin tinggi pula kualitas laba tersebut. Penelitian ini dilakukan oleh Dewi \& Putri, (2015); Ariyani \& Wulandari, (2017); Satyawati \& Palupi, (2017); Yulia et al., (2018); Ahnan \& Murwaningsari, (2019). Hasil penelitian menyatakan bahwa semakin besar arus kas operasi periode sekarang maka laba akuntansi sebelum pajak satu periode mendatang akan cenderung meningkat, begitu juga sebaliknya, sehingga dengan semakin besarnya arus kas operasi, persistensi laba dimasa mendatang akan dapat terjaga dengan baik. Penelitian ini bertolak belakang dengan Dillak et al., (2017); Magfiroh \& Kusmuriyanto, (2018) menyatakan bahwa arus kas tidak mempengaruhi persistensi laba.

Dalam upaya meningkatkan laba, perusahaan berusaha untuk memaksimalkan sumber daya yang dimiliki serta meminimalkan biaya yang dikeluarkan. Berdasarkan data Bursa Efek Indonesia untuk sektor perbankan dari tahun 2014 - 2018 mengindikasikan tingkat persistensi laba sebagai berikut:

Tabel 1. Rata-rata Tingkat Perbedaan Temporer, Perbedaan Permanen, Arus Kas Operasi dan Persistensi Laba

\begin{tabular}{ccccc}
\hline Tahun & P. Temporer & P. Permanen & OCF & Persistensi laba \\
\hline 2014 & $-0,00021$ & 0,00085 & 0,0476 & 0,01308 \\
2015 & 0,0001 & 0,00178 & 0,0022 & 0,01083 \\
2016 & 0,00301 & 0,00125 & $-0,0047$ & 0,00628 \\
2017 & 0,00156 & 0,00085 & 0,0173 & 0,00815 \\
2018 & 0,0015 & 0,0006 & $-0,0012$ & 0,0114 \\
\hline \multicolumn{4}{c}{ Sumber: Laporan keuangan BEI, Data diolah kembali oleh penulis (2019) }
\end{tabular}

Sepanjang tahun 2014 sampai 2016 persistensi laba mengalami penurunan. Penurunan terbesar terjadi pada tahun 2016 sebesar 0,4\% dari tahun sebelumnya. Berdasarkan nilai persistensinya pada tahun 2016 terdapat 12 perusahaan yang menunjukkan angka negatif. PT Bank Pundi Indonesia Tbk berada di tingkat terendah dengan minus 0,085 (8,5\%) dan PT Bank Harda Internasional Tbk mencapai minus 0,038 (3,8\%). PT Bank Pundi Indonesia Tbk selama 5 tahun terakhir selalu mengalami kerugian berbeda dengan PT Bank Harda Tbk yang mengalami tren naik turun. Berbanding terbalik dengan persistensi laba, perbedaan temporer selama tahun 2014 sampai dengan 2016 justru mengalami kenaikan sebesar 3\%. Secara teoritis, jika persistensi laba menurun maka perbedaan temporer meningkat maupun sebaliknya (Jackson, 2015). Rata-rata perbedaan permanen dan arus kas operasional mengalami kenaikan dan penurunan yang tidak stabil.

Berdasarkan penjelasan latar belakang dan fenomena di atas, penulis melakukan penelitian lanjutan untuk memberikan simpulan yang diharapkan dapat lebih memberikan kejelasan terkait pengaruh book tax difference dan arus kas operasional terhadap persistensi laba.

\section{METEDOLOGI PENELITIAN}

\subsection{Teori Sinyal}


Landasan signalling theory yaitu pengungkapan sukarela yang berupa informasi mengenai upaya yang sudah dilakukan oleh manajemen untuk merealisasikan keinginan pemilik. Infomasi dapat berbentuk laporan keuangan, informasi kebijakan perusahaan, atau informasi lain yang diungkapkan oleh perusahaan. Sinyal juga dapat berupa promosi atau informasi lain yang dapat menyatakan bahwa perusahaan tersebut lebih baik daripada perusahaan lain. Dalam penelitian ini diharapkan BTD dan arus kas operasional dapat memberikan prediksi mengenai besarnya laba yang diperoleh oleh perusahaan. Kemudian berdasarkan sinyal ini, Investor dapat mengetahui mana perusahaan yang memiliki laba yang persisten dan mana yang tidak. Manajemen selalu berusaha untuk mengungkapkan informasi privat yang menurut pertimbangannya sangat diminati investor dan pemegang saham khususnya jika informasi tersebut merupakan berita baik atau good news (Connelly, 2011). Apabila informasi tersebut positif (baik), maka pasar akan bereaksi terhadap pengumuman tersebut.

\subsection{Persistensi Laba}

Persistensi laba dapat digunakan sebagai salah satu proksi perhitungan kualitas laba (Dechow et al., (2010); Martinez \& De Souza, (2016); Magfiroh \& Kusmuriyanto, (2018); Ahnan \& Murwaningsari, (2019)). Persistensi laba menunjukkan laba yang berkualitas dapat dilihat dari pendapatan berkelanjutan. Pendapatan berkualitas tinggi tidak hanya memberikan ringkasan kinerja masa lalu, tetapi juga harus memberikan panduan untuk masa depan (Sloan, (1996); Penman dan Zhang, (2002); Francis et al., (2004); Richardson et al., (2005); Addeh, (2016)). Teori persistensi laba berfokus pada kegunaan laporan pendapatan kepada investor. Idenya adalah bahwa laba yang persisten (kurang stabil) lebih berguna bagi investor dalam membuat keputusan tentang nilai ekuitas perusahaan saat ini dan prospek masa depan (Martinez \& De Souza, 2016).

\subsection{Book Tax Difference}

Perbedaan laba akuntansi dan laba fiskal disebabkan oleh perbedaan peraturan yang mengatur dasar penyusunan laporan keuangan, antara laporan keuangan komersial atau konvensial dengan keuangan fiskal atau pajak. Laporan keuangan komersial diatur dengan SAK, sedangkan laporan keungan komersial diatur berdasarkan peraturan perundang-undangan. Laba fiskal dapat diketahui dengan membuat rekonsiliasi fiskal. Perbedaan pengakuan penghasilan dan biaya antara akuntansi komersial dan fiskal menyebabkan terjadinya perbedaan temporer dan permanen.

Perbedaan temporer adalah perbedaan antara jumlah tercatat aset atau liabilitas pada posisi keuangan dengan dasar pengenaan pajaknya (SAK No. 46). Perbedaan temporer dapat berupa perbedaan temporer kena pajak dan perbedaan temporer dapat dikurangkan. Perbedaan temporer terjadi karena perbedaan waktu pengakuan namun secara total nilai penghasilan dan beban yang diakui jumlahnya sama. Perbedaan temporer akan diakui sebagai pendapatan atau beban pajak tangguhan dan sebagai konsekuensinya akan diakui sebagai aset dan liabilitas pajak tangguhan dalam laporan posisi keuangan. Perbedaan temporer dapat dipulihkan atau diselesaikan di masa mendatang, sehingga konsekuensi perbedaan atas pengakuan aset liabilitas tertentu akan hilang ketika perbedaan tersebut tidak ada lagi. Beberapa kejadian yang merupakan perbedaan temporer yaitu pengakuan beban provisi garansi, depresiasi, pengakuan beban penyisihan piutang, pengakuan pendapatan.

Perbedaan permanen adalah perbedaan antara laba sebelum pajak (akuntansi) dengan penghasilan kena pajak yang tidak dapat terpulihkan dimasa depan (Martani et al., 2016:259). Perbedaan tersebut membuat laba menurut akuntansi berbeda dengan laba menurut pajak, namun perbedaannya tersebut tidak akan diakui sebagai pajak tangguhan. Perbedaan permanen atau tetap terjadi karena transaksi-transaksi pendapatan dan biaya diakui menurut akuntansi komersial tidak diakui menurut fiskal. Perbedaan tetap mengakibatkan laba (rugi) bersih menurut akuntansi berbeda (secara tetap) dengan penghasilan (laba) kena pajak menurut fiskal. Berdasarkan buku Resmi (2014: 403) contoh perbedaan tetap adalah:

1. Penghasilan yang pajaknya bersifat final, seperti bunga bank, dividen, sewa tanah dan bangunan dan penghasilan lain sebagaimana diatur dalam pasal 4 ayat (2) UU PPh.

2. Penghasilan yang tidak termasuk objek pajak, seperti dividen yang diterima perseroan terbatas, koperasi, BUMN/BUMD, bunga yang diterima oleh perusahaan reksadana, dan penghasilan yang diatur dalam pasal 4 ayat (3) UU PPh.

3. Biaya/ pengeluaran yang tidak diperbolehkan sebagai penghasilan bruto, seperti pembayaran imbalan dalam bentuk natura, sumbangan, biaya/ pengeluaran untuk kepentingan pribadi pemilik, cadangan atau pemupukan dana cadangan, pajak penghasilan, dan biaya atau pengurang lain yang tidak diperbolehkan (nondeductible expenses) menurut fiskal sesuai pasal pasal 9 ayat (1) dan (2) UU PPh.

\subsection{Arus Kas Operasional}

Aktivitas operasi (operating activities) merupakan transaksi-transaksi kegiatan operasional yang dilaporkan dalam laba rugi (Martani, 2016:384). Perusahaan menentukan jumlah arus kas operasi dengan mengonversi laba neto berdasarkan basis akrual menjadi laba neto berdasarkan basis kas. Untuk melakukannya, perusahaan menambah atau mengurangi dari laba bersih pos-pos dalam laba rugi yang tidak memengaruhi kas. Prosedur ini mengharuskan perusahaan menganalisi tidak hanya laporan rugi tahun berjalan, tetapi juga laporan posisi keuangan komparatif dan transaksi tertentu (Kieso, 2019:260). 
Penerimaan kas dari penjualan barang atau jasa merupakan sumber arus kas yang utama. Penerimaan kas lainnya berasal dari pendapatan bunga, dari pinjaman yang diberikan, pendapatan dividen dan penjualan sekuritas yang diperdagangkan. Sedangkan arus kas keluar meliputi pembayaran kepada pemasok (supplier) atas persediaan, membayar gaji atau upah kepada karyawan, pembayaran pajak kepada pemerintah, pembayaran bunga kepada kreditur, beban utilitas, sewa dan pembelian sekuritas yang diperdagangkan.

\subsection{Kerangka Konseptual}

Berdasarkan variabel penelitian dan hipotesis diatas, kerangka konseptual penelitian disusun sebagai berikut :

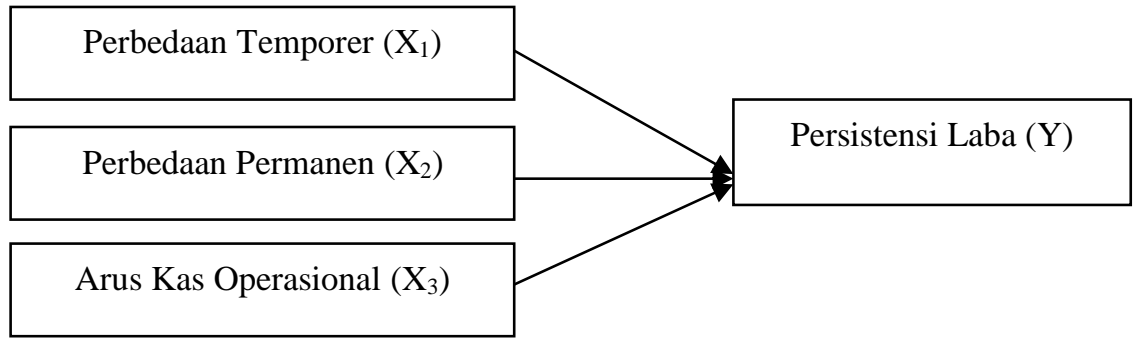

Gambar 1. Hubungan Variabel

\subsection{Hipotesis}

Sumber: data diolah oleh penulis (2019)

\section{Perbedaan temporer berpengaruh negatif terhadap peristensi laba}

Perbedaan temporer bersifat sementara terjadi ketika aturan akuntansi dan hukum pajak mengenai nomor transaksi tertentu berbeda waktu pengakuannya. Sehingga akan dilakukan koreksi positif atau negatif. Koreksi ini menyebabkan penghasilan kena pajak menjadi lebih besar ataupun lebih kecil dari laba sebelum pajak menurut akuntansi. Beberapa penelitian sebelumnya yang menunjukkan hubungan negatif antara perbedaan temporer dengan persistensi laba diantaranya Martinez et al., (2013); Jackson, (2015); Addeh, (2016); Waluyo, (2016); Praptitorini \& Rahmawati, (2017); Ariyani \& Wulandari, (2017); Adiati, Rahmawati \& Bandi, (2018)

\section{Perbedaan permanen berpengaruh positif terhadap persistensi laba}

Perbedaan tetap biasanya timbul karena undang-undang pajak bahwa beberapa transaksi yang tidak dimasukkan perhitungan penghasilan kena pajak. Menurut Undang-Undang Pajak Penghasilan, beberapa item yang merupakan perbedaan permanen pajak penghasilan final (Pasal 4 ayat 2), objek tidak kena pajak (Pasal 4 ayat 3), dan biaya yang tidak diperbolehkan pendapatan kotor (Pasal 9 ayat 1). Perbedaan sebagai pembentuk BTD menyebabkan adanya koreksi fiskal baik positif maupun negatif. Koreksi positif menyebabkan laba fiskal bertambah. Jika laba fiskal bertambah maka beban pajak yang harus dibayarkan semakin besar. Semakin besar beban pajak yang dibayarkan maka semakin kecil laba bersih yang dihasilkan begitupun sebaliknya. Maka dari itu perbedaan permanen berpengaruh positif terhadap persistensi laba. Penelitian ini sejalan dengan penelitian Martinez et al., (2013), Dewi \& Putri (2015); Jackson (2015), Waluyo (2016), Addeh (2016), Ahnan \& Murwaningsari (2019).

Arus kas operasional berpengaruh positif signifikan terhadap persistensi laba.

Data arus kas merupakan indikator keuangan yang lebih baik dibandingkan dengan akuntansi karena arus kas relatif lebih sulit untuk dimanipulasi..Sehingga semakin tingginya aliran kas operasi terhadap laba maka akan semakin tinggi pula kualitas laba tersebut. Hasil penelitian yang dilakukan oleh Dewi \& Putri, (2015); Satyawati dan Palupi, (2017); Ariyani \& Wulandari, (2017); Yulia et al., (2018); serta Ahnan \& Murwaningsari, (2019) menyatakan bahwa aliran kas operasi berpengaruh positif dan signifikan terhadap persistensi laba.

\subsection{Metode Penelitian}

Penelitian ini menggunakan pendekatan metode kuantitatif. Data diperoleh dari data sekunder berupa laporan keuangan tahunan yang telah diaudit di Bursa Efek Indonesia (BEI) tahun 2014-2018. Populasi yang digunakan dalam penelitian ini adalah seluruh perusahaan perbankan dan jasa keuangan yang terdaftar di Bursa Efek Indonesia pada tahun 20142018. Teknik pengambilan sampel menggunakan teknik purposive sampling dengan kriteria sebagai berikut:

1) Perusahaan perbankan dan jasa keuangan yang terdaftar di Bursa Efek Indonesia (BEI) pada tahun 2014- 2018 secara berturut- turut.

2) Mempublikasikan laporan keuangan yang telah di audit selama tahun penelitian.

3) Laporan keuangan dinyatakan dalam mata uang rupiah, karena penelitian dilakukan di Indonesia.

4) Perusahaan tidak mengalami kerugian dalam laporan keuangan komersial dan laporan keuangan fiskal selama tahun pengamatan.

5) Memiliki kelengkapan informasi yang dibutuhkan terkait dengan indikator-indikator perhitungan yang dijadikan variabel pada penelitian ini. 


\subsection{Operasional Variabel}

Dalam penelitian ini terdapat tiga variabel independen yang diteliti yaitu perbedaan temporer (X1), perbedaan permanen (X2), arus kas operasional (X3)

\subsubsection{Perbedaan Temporer}

Besar perbedaan temporer diketahui dari total perbedaan temporer pada catatan atas laporan keuangan dan dibagi dengan total aset (Jackson, (2009); Martinez et al., (2016); Waluyo, (2016); Dillak et al., (2017); Ahnan \& Murwaningsari, (2019)).

$$
\mathrm{PD}=\frac{\text { Jumlah perbedaan temporer rekonsiliasi fiskal }}{\text { Total Aset }}
$$

\subsubsection{Perbedaan Permanen}

Besarnya perbedaan permanen diketahui dari total perbedaan permanen dalam catatan atas laporan keuangan dan dibagi dengan total aset (Jackson, (2009); Martinez et.al., (2016); Waluyo, (2016); Dillak et al., (2017); Ahnan \& Murwaningsari, (2019)).

$$
\mathrm{TD}=\frac{\text { Jumlah perbedaan permanen rekonsiliasi fiskal }}{\text { Total aset }}
$$

\subsubsection{Arus Kas Operasional}

Besarnya arus kas operasional yang digunakan dalam penelitian ini dihitung berdasarkan arus kas operasi (operating cash flow) pada tahun berjalan dibagi dengan total aset (Dillak et al., (2017); Yulia et al., 2018; Ahnan \& Murwaningsari, 2019).

$$
\text { OCF }=\frac{\text { Arus Kas Operasional }}{\text { Total Aset }}
$$

\subsubsection{Persistensi Laba}

Pengukuran persitensi laba dapat dilihat dari koefisien regresi $\left(\gamma_{1}\right)$ antara laba akuntansi sebelum pajak satu periode masa depan (PTBI ${ }_{t+1}$ ) dengan laba akuntansi sebelum pajak periode sekarang $\left(\mathrm{PTBI}_{\mathrm{t}}\right)$. Laba akuntansi dianggap semakin persisten apabila koefisien regresinya semakin kecil.

$$
\mathrm{PTBI}_{\mathrm{t}+1}=\mathrm{\gamma}_{0}+\mathrm{\gamma}_{1} \mathrm{PTBI}_{\mathrm{t}}+\mathrm{v}_{\mathrm{t}}
$$

Penelitian ini untung menguji pengaruh perbedaan temporer, perbedaan permanen dan arus kas operasional terhadap Persistensi Laba. Analisis data yang digunakan adalah uji asumsi klasik yang terdiri dari uji normalitas, uji autokorelasi, uji multikolinearitas, dan uji heteroskedastisitas. Uji hipotesis yang terdiri dari uji regresi linear berganda, uji t dan uji koefisien determinasi $\left(\mathrm{R}^{2}\right)$. Persamaan regresi linear berganda disajikan sebagai berikut :

$$
\mathrm{PRST}=\alpha+\mathrm{X}_{1} \mathrm{TD}+\mathrm{X}_{2} \mathrm{PD}+\mathrm{X}_{3} \mathrm{OCF}+\mathrm{e}
$$

$\begin{array}{ll}\text { Keterangan: } & \\ \text { PRST } & =\text { Persistensi Laba } \\ \text { TD } & =\text { Perbedaan Temporer } \\ \text { PD } & =\text { Perbedaan Permanen } \\ \text { OCF } & =\text { Arus Kas Operasional } \\ \alpha & =\text { Konstanta } \\ \mathrm{X}_{1}-\mathrm{X}_{3}=\text { Koefisien } & \\ \mathrm{e} & =\text { Error }\end{array}$

\section{HASIL DAN PEMBAHASAN}

\subsection{Sampel Penelitian}

Berdasarkan hasil dari proses seleksi sampel terdapat 33 perusahaan yang telah memenuhi syarat sebagai sampel penelitian dengan periode penelitian 5 tahun. Sehingga diperoleh sebanyak 165 total observasi. Berdasarkan data observasi tersebut, untuk mendapatkan data yang normal dilakukan tahapan outlier sebanyak 5 kali dengan total 30 data. Jadi total sampel yang diolah dalam penelitian ini adalah 135 observasi.

\subsection{Uji Asumsi Klasik}

\subsubsection{Hasil Uji Normalitas}

Hasil Uji Normalitas menggunakan uji non-parametrik Kolmogorov smirnov diperoleh nilai probabilitas sebesar 0,200. Nilai ini lebih besar dibandingkan dengan 0,05 (taraf signifikan sebesar 5\% atau $\alpha=5 \%$ ). Maka dapat disimpulkan bahwa data terdistribusi secara normal. 
Ekonomi, Keuangan, Investasi dan Syariah (EKUITAS)

Vol 3, No 2, November 2021, Hal 114-123

ISSN 2685-869X (media online)

DOI 10.47065/ekuitas.v3i2.1072

Tabel 2. Hasil Uji Normalitas

\begin{tabular}{llr}
\hline & One-Sample Kolmogorov-Smirnov Test & Unstandardized Residual \\
\hline $\mathrm{N}$ & & 135 \\
Normal Parameters ${ }^{\mathrm{a}, \mathrm{b}}$ & Mean &, 0000000 \\
& Std. Deviation &, 00916569 \\
Most Extreme Differences & Absolute &, 068 \\
& Positive &, 068 \\
Test Statistic & Negative &,- 068 \\
Asymp. Sig. (2-tailed) & &, 068 \\
a. Test distribution is Normal. &, $200^{\text {c,d }}$ \\
b. Calculated from data. & & \\
c. Lilliefors Significance Correction. & \\
d. This is a lower bound of the true significance. & \\
\hline
\end{tabular}

Sumber : Olah data SPSS 25(2019)

\subsubsection{Hasil Uji Autokorelasi}

Tabel 3. Hasil Uji Autokorelasi

\begin{tabular}{|c|c|c|c|c|c|}
\hline \multicolumn{6}{|c|}{ Model Summary } \\
\hline Model & $\mathrm{R}$ & R Square & Adjusted R Square & $\begin{array}{l}\text { Std. Error of the } \\
\text { Estimate }\end{array}$ & Durbin-Watson \\
\hline 1 &, $746^{\mathrm{a}}$ &, 557 & ,547 &, 0081155 & 2,101 \\
\hline $\begin{array}{l}\text { a. Prec } \\
\text { b. Dep }\end{array}$ & $\begin{array}{l}\text { (Constan } \\
\text { Variable }\end{array}$ & $\begin{array}{l}\text {, OCF, PD, } \\
\text { PRST }\end{array}$ & TD & & \\
\hline
\end{tabular}

Sumber : Olah data SPSS 25(2019)

Berdasarkan tabel 4.5 hasil uji autokorelasi menunjukkan bahwa nilai DW sebesar 2,101 tersebut berada pada nilai interval $\mathrm{du}<\mathrm{d}<4-\mathrm{du}=1,7645<2,101<2,2355$. Hasil pengujian ini dapat disimpulkan bahwa tidak terjadi gejala autokorelasi positif maupun negatif pada model regresi yang digunakan.

\subsubsection{Hasil Uji Multikolinearitas}

Tabel 4. Hasil Uji Multikolinearitas Tolerance dan VIF

\begin{tabular}{llrr}
\hline & \multicolumn{2}{c}{ Collinearity Statistics } \\
& Tolerance & VIF \\
\hline 1 & (Constant) &, 999 & 1,001 \\
& TD &, 986 & 1,014 \\
PD &, 987 & 1,013 \\
OCF & & \\
&
\end{tabular}

Sumber: Olah data SPSS 25(2019)

Dari tabel diatas menunjukkan bahwa perbedaan temporer, perbedaan permanen dan arus kas operasional memiliki nilai tolerance $\geq 0,10$ dan nilai VIF $\leq 10$. Maka dapat disimpulkan bahwa tidak terdapat masalah multikolinearitas antara variabel independen dalam model regresi.

\subsubsection{Hasil Uji Heteroskedastisitas}

Hasil uji heteroskedastisitas dalam penelitian ini adalah sebagai berikut:

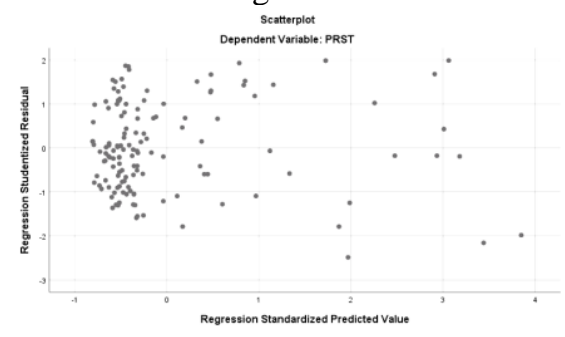

Gambar 2. Hasil Uji Heteroskedastisitas Sumber: olah data SPSS 25 (2019) 
Tabel 5. Hasil Uji Heteroskedastisitas dengan Uji Park

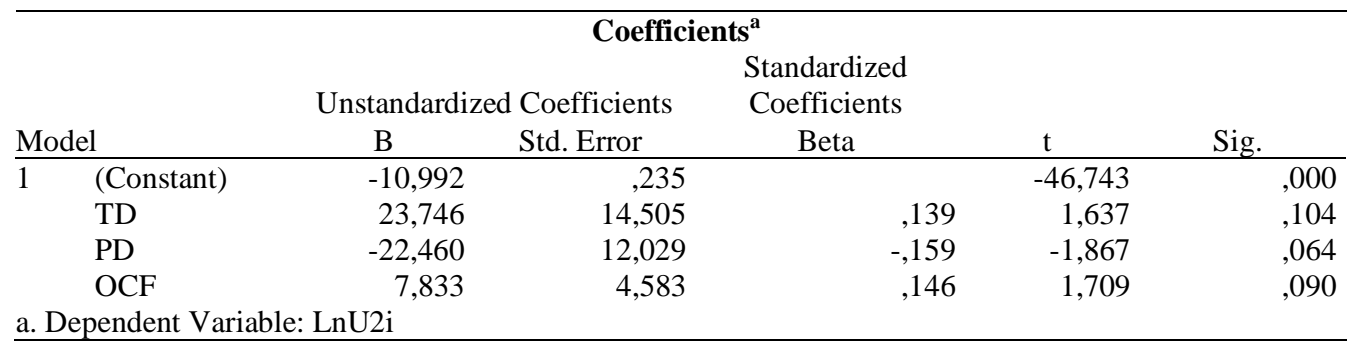

Sumber: olah data SPSS (2019)

Hasil tampilan output SPSS menunjukkan bahwa scatterplot menyebar diatas dan dibawah angka 0 serta koefisien untuk variabel independen tidak ada yang signifikan, maka dapat disimpulkan bahwa model regresi tidak terjadi heteroskedastisitas. Hasil ini konsisten dengan hasil uji scatterplots.

\subsection{Uji Regresi Linear Berganda}

Tabel 6. Hasil Uji Analisis Linier Berganda

\begin{tabular}{|c|c|c|c|c|c|c|}
\hline \multicolumn{7}{|c|}{ Coefficients $^{\mathrm{a}}$} \\
\hline \multirow{2}{*}{\multicolumn{2}{|c|}{ Model }} & \multicolumn{2}{|c|}{$\begin{array}{c}\text { Unstandardized } \\
\text { Coefficients }\end{array}$} & \multicolumn{3}{|l|}{$\begin{array}{c}\text { Standardized } \\
\text { Coefficients }\end{array}$} \\
\hline & & B & Std. Error & Beta & $\mathrm{t}$ & Sig. \\
\hline 1 & (Constant) & ,026 & ,001 & & 25,345 & 000 \\
\hline & TD & ,478 &, 062 & ,376 & 7,671 & ,000 \\
\hline & PD &,- 794 & 052 &,- 757 & $-15,364$ & ,000 \\
\hline & $\mathrm{OCF}$ &, 042 &, 020 &, 105 & 2,131 & ,035 \\
\hline & pendent $\mathrm{Va}$ & RST & & & & \\
\hline
\end{tabular}

Sumber: olah data SPSS 25 (2019)

Berdasarkan hasil dari coefficients diatas dapat dikembangkan dengan model persamaan regresi linier berganda sebagai berikut:

$$
\begin{gathered}
\text { PRST }=\mathrm{a}+\mathrm{b} 1 \mathrm{TD}+\mathrm{b} 2 \mathrm{PD}+\mathrm{b3OCF}+\mathrm{e} \\
\text { PRST }=0,026+0,478 \text { TD }-0,794 \mathrm{PD}+0,042 \text { OCF }+\mathrm{e}
\end{gathered}
$$

\subsection{Uji Hipotesis}

\subsubsection{Hasil Uji t}

1. Variabel perbedaan temporer (TD) berhubungan positif (B1) terhadap persistensi laba (PRST) dengan nilai thitung sebesar 7,671 > $\mathrm{t}_{\text {tabel }} 1,65648$ dan nilai signifikansi sebesar 0,000 $<0,05$ berarti $\mathrm{H}_{1}$ ditolak. Hal ini berarti bahwa perbedaan temporer berpengaruh positif dan signifikan terhadap persistensi laba. Jika beda temporer mengalami kenaikan, maka akan menyebabkan kenaikan pula terhadap tingkat persistensi laba perusahaan.

2. Variabel perbedaan permanen (PD) berhubungan negatif (B2) dan nilai $t_{\text {hitung }}$ sebesar $-15,364<\mathrm{t}_{\text {tabel }}$ 1,65648 dan nilai signifikansi $0,000<0,05$ berarti $\mathrm{H}_{2}$ ditolak. Ini berarti bahwa perbedaan permanen berpengaruh negatif signifikan terhadap persistensi laba. Perbedaan permanen yang meningkat dapat menurunkan tingkat persistensi laba.

3. Variabel arus kas operasional (OCF) berpengaruh positif (B3) dan nilai $t_{\text {hitung }}$ sebesar 2,131 $>t_{\text {tabel }}$ 1,65648 dan nilai signifikansi $0,035<0,05$ dan, berarti $\mathrm{H}_{3}$ diterima. Ini menunjukkan bahwa arus kas operasional berpengaruh positif dan signifikan terhadap persistensi laba. Jika arus kas operasi dalam suatu perusahaan meningkat akan menyebabkan kenaikan pula terhadap tingkat persistensi laba.

\subsubsection{Hasil Uji Determinasi $\mathbf{R}^{2}$}

Besarnya adjusted $\mathrm{R}^{2}$ berdasarkan hasil analisis dengan menggunakan SPSS diperoleh sebesar 0,547 (54,7\%). Dengan demikian perbedaan temporer, perbedaan permanen dan arus kas operasional dapat menjelaskan bahwa persistensi laba dipengaruhi 54,7\% oleh variabel tersebut. sedangkan sisanya dipengaruhi oleh faktor lain diluar model penelitian ini. Hasil dari persamaan regresi linier berganda dan simpulan hipotesis dapat dijelaskan sebagai berikut:

\section{Pengaruh perbedaan temporer terhadap persistensi laba}

Hasil pengujian perbedaan temporer terhadap persistensi laba mempunyai koefisien regresi sebesar 0,478 bernilai positif dengan nilai signifikansi sebesar 0,000 lebih kecil dari 0,05. Artinya, terdapat hubungan searah dan signifikan antara perbedaan temporer dengan persistensi laba.

Dalam penelitian ini hubungan positif antara perbedaan temporer dan persistensi laba menunjukkan bahwa, sebagian besar perbedaan temporer dalam sampel merupakan perbedaan temporer yang dapat dikurangkan, maka akan timbul aset pajak tangguhan dan akan berpengaruh pada kecilnya laba setelah pajak tahun ini tetapi akan meningkat 
dimasa mendatang. Hal ini sesuai dengan definisi persistensi laba yang menyatakan bahwa laba yang persisten dapat dipertahankan dan ditingkatkan pada tahun berikutnya.

Hasil penelitian ini sesuai dengan penelitian sebelumnya yang dilakukan oleh Ahnan \& Murwaningsari, (2019); Dewi \& Putri (2015); dan Racca, (2011) yang menyatakan bahwa perbedaan temporer berpengaruh positif terhadap persistensi laba. Namun, hasil penelitian ini bertolak belakang dengan penelitian yang dilakukan Adiati, Rahmawati \& Bandi, (2018); Ariyani \& Wulandari, (2017); Praptitorini \& Rahmawati, (2017); Waluyo, (2016); Addeh, (2016); dan Martinez et al., (2013) yang membuktikan bahwa perbedaan temporer berpengaruh negatif terhadap persistensi laba.

\section{Pengaruh perbedaan permanen terhadap persistensi laba}

Hasil pengujian perbedaan permanen terhadap persistensi laba mempunyai nilai koefisien regresi $-0,794$ bernilai negatif dan signifikansi sebesar 0,000 lebih kecil dari 0,05. Artinya, variabel perbedaan permanen memiliki pengaruh negatif dan signifikan terhadap persistensi laba. Semakin besar nilai perbedaan permanen menyebabkan persistensi laba semakin kecil, begitupun sebaliknya.

Sesuai dengan sifatnya, perbedaan permanen tidak akan diperhitungkan dengan laba kena pajak tahun berikutnya. Ketika periode sekarang suatu penghasilan/biaya tidak diakui menurut undang-undang pajak, maka pada periode berikutnya juga tidak dapat diakui sebagai penghasilan/ biaya di laporan laba/ rugi fiskal. Koreksi positif (negatif) pada perbedaan permanen akan mengakibatkan beban pajak dimasa mendatang menjadi lebih tinggi (rendah). Beban pajak yang besar akan menghasilkan laba yang lebih rendah, begitupun sebaliknya. Laba (rugi) bersih menurut akuntansi akan berbeda (secara tetap) dengan penghasilan kena pajak menurut fiskal. Sehingga perbedaan permanen yang tetap dari tahun ke tahun akan menghasilkan laba yang lebih persisten atau sesuai dengan yang diharapkan.

Hasil penelitian ini konsisten dengan penelitian sebelumnya yang dilakukan oleh Praptitorini \& Rahmawati, (2017); Ariyani \& Wulandari, (2017); Dillak et al., (2017) yang membuktikan bahwa perbedaan permanen berpengaruh negatif terhadap persistensi laba. serta Jackson, (2015) yang membuktikan bahwa perbedaan permanen berpengaruh negatif dengan memasukan manajemen laba sebagai variabel moderating. Namun, penelitian ini bertolak belakang dengan penelitian Ahnan \& Murwaningsari, (2019); Waluyo, (2016); Addeh, (2016); Dewi \& Putri, (2015); dan Martinez et al., (2013); yang menyatakan bahwa perbedaan permanen berpengaruh ke arah positif terhadap persistensi laba.

\section{Pengaruh arus kas operasional terhadap persistensi laba}

Hasil pengujian arus kas operasional terhadap persistensi laba mempunyai nilai koefisien regresi 0,042 bernilai positif dan signifikansi sebesar 0,035 lebih kecil dari 0,05. Artinya, variabel perbedaan permanen memiliki pengaruh positif dan signifikan terhadap persistensi laba.

Pada dasarnya, arus kas merupakan indikator yang keuangan yang lebih baik. Semakin tinggi nilai arus kas operasi pada perusahaan, maka tingkat persistensi laba semakin meningkat. Hal ini disebabkan karena perusahaan lebih banyak mendapatkan kas dibandingkan mengeluarkannya, dengan kata lain perusahaan memiliki kas untuk melakukan operasionalnya kembali tanpa harus meminjam/mencari modal kepada pihak lain.

Temuan ini konsisten dengan hasil penelitian Ahnan \& Murwaningsari, (2019); Yulia et al., (2018); Satyawati \& Palupi, (2017); Ariyani \& Wulandari, (2017); serta Dewi \& Putri, (2015) yang membuktikan bahwa arus kas memiliki pengaruh positif terhadap persistensi laba. Namun, penelitian ini tidak sejalan dengan penelitian Magfiroh \& Kusmuriyanto, (2018); dan Dillak et al., (2017) yang menyatakan bahwa tidak ada pengaruh antara arus kas operasi terhadap persistensi laba.

\section{KESIMPULAN}

Setelah melakukan beberapa analisis, maka hasil penelitian berdasarkan rumusan masalah disimpulkan perbedaan temporer berpengaruh positif dan signifikan terhadap persistensi laba. Artinya, perbedaan temporer yang tinggi atau meningkat, akan mengakibatkan tingkat persistensi laba yang lebih tinggi dimasa mendatang. Hal ini disebabkan karena perbedaan temporer diakui sebagai pendapatan pajak tangguhan sehingga dapat menjadi pengurang beban pajak, akibatnya laba akan meningkat. Perbedaan permanen berpengaruh negatif dan signifikan terhadap persistensi laba. Artinya, semakin tinggi nilai perbedaan permanen, maka dapat menurunkan tingkat persistensi laba, karena beban pajak yang dihasilkan dari perbedaan permanen juga semakin besar akibatnya laba perusahaan menjadi lebih kecil. Arus kas operasional berpengaruh positif dan signifikan terhadap persistensi laba. Artinya, semakin besar saldo kas operasi yang digunakan dalam perusahaan menunjukkan persistensi laba yang lebih tinggi (baik), karena perusahaan mampu membiayai kegiatan operasionalnya tanpa harus meminjam/mencari modal kepada pihak lain. Berdasarkan hasil penelitian yang telah dilakukan maka diajukan saran bahwa perbedaan temporer harus dievaluasi setiap periode untuk memastikan bahwa perbedaan temporer tersebut dapat dikurangkan atau tidak. Jika perbedaan temporer tersebut tidak dapat dikurangkan, maka aset pajak tangguhan yang timbul dari perbedaan tersebut tidak boleh diakui lagi. Perusahaan dapat melakukan perencanaan pajak yang baik sehingga mengoptimalkan pajak yang dibayarkan, namun tetap taat mengikuti aturan perpajakan. Misalnya dengan menghindari biaya yang menurut pajak tidak diperbolehkan (non deductible expenses) sehingga koreksi positif pada perbedaan permanen yang berdampak pada penghasilan kena pajak dapat diminimalkan. Perusahaan sebaiknya dapat mempertahankan atau meningkatkan saldo kas operasi yang digunakan dalam perusahaan. Karena semakin besar arus kas operasi dapat menunjukkan persistensi laba yang lebih 
tinggi. Sehingga akan mendorong investor tertarik melakukan investasi pada perusahaan tersebut. Dalam proses penelitian ini masih terdapat beberapa keterbatasan diantaranya yaitu variabel independen yang digunakan dalam penelitian ini hanya menjelaskan $54,7 \%$ dari variabel dependen, sisanya dipengaruhi oleh variabel lain yang tidak dimasukkan dalam penelitian. Sehingga untuk peneliti selanjutnya sebaiknya menambahkan variabel lain seperti tingkat hutang, pertumbuhan penjualan, inventory turnover, ukuran perusahaan, kepemilikan manajerial dan lain sebagainya.

\section{REFERENCES}

Adiati, Rahmawati, dan Bandi. 2018. The Impact of Deferred Tax and Accruals on the Earnings Persistence of Companies in the Non-Financial Sectors Listed on the Indonesia Stock Exchange. Journal of Accounting, Finance and Auditing Vol 4(3): 1-18.

Arikunto, Suharsimi. 2013. Prosedur Penelitian: Suatu Pendekatan Praktik. Jakarta: Rineka Cipta.

Ariyani, Dian dan Wulandari Rosita. 2017. Pengaruh Book Tax Differences dan Arus Kas terhadap Persistensi Laba. Jurnal Keberlanjutan Vol. 2(2).

Blaylock, Bradley, Shevlin dan Wilson. 2012. Tax Avoidance, Large Positive Temporary Book Tax Difference, and Earnings Persistence. The Accounting Review American Accounting Association Vol 87 (1): 91-120

Brian L. Connelly, S. Trevis Certo, R. Duane Ireland dan Christopher R. Reutzel. 2011. Signaling Theory: A Riview and Assesment. Journal of Management Southem Management Association.

Cahya, Annas dan Sumiyana. 2013. The Role of Temporary Difference of Book Value and Tax Based Earnings To Explain Earnings Persistence. The Indonesian Journal of Accounting Research.

Dechow, P. M., W. Ge, dan C. Schrand. 2010. Understanding Earnings Quality: A Review of the Proxies, Their Determinants, and Their Consequences. Journal of Accounting and Economics 50 (2-3), 344-401.

Dewi, Ni Putu Lestari dan I.G.A.M Asri Dwija Putri. 2015. Pengaruh Book-Tax Difference, Arus Kas Operasi, dan Ukuran Perusahaan pada Persistensi Laba. E-Jurnal Akuntansi Universitas Udayana Vol 10 No 1. ISSN 2302-8556.

Dridi, Wiem dan Adel Boubaker.2016. Book-Tax Differences and Persistence of Earnings and Accrual: Tunisian . Asian Social Science Vol.12: 193-202.

Ghozali, Imam. 2018. Aplikasi Analisis Multivariate dengan Program SPSS. Edisi 9. Semarang: Badan Penerbit Universitas Diponegoro.

Jackson, Mark. 2009. Book Tax Difference and Earnings Growth. Working Paper: University of Oregon.

Jackson, Mark. 2015. Book-Tax Differences and Future Earnings Changes. College of Business University of Nevada. The American Accounting Journal Vol 37, Issue 2:49-73.

Kamarudin, K.A dan Ismail, W.A.W. 2014. Earnings Quality Construct and Measures in Empirical Accounting Studies. International Conference on Governance \& Strategic Management (ICGSM).

Kieso, D.E.,Weygandt J.J, dan Warfield T.D. 2019. Akuntansi Keungan Menengah, Volume 1 Edisi IFRS terjemahan. Jakarta: Salemba Empat.

Lev, B dan D. Nissim. 2004. Taxable Income, Future Earnings, and Equity Values. The Accounting Review (Oktober). pp 1039-1074.

Maftuh Ahnan, Zuhal dan Etty Murwaningsary.2019. The Effect Of Book-Tax Differences, and Executive Compensation on Earnings Persistence with Real Earnings Management as Moderating Variabel. Research Journal Of Finance and Accounting, Vol.10: 54-63.

Magfiroh, C.S dan Kusmuriyanto.2018. The Influence of Book Tax Differences, Operating Cash Flow, Leverage, and Firm Size towards Earnings Persistence. Accounting Analysis Journal Vol 7 No 3, hal 151-158.

Marnilin, Feni dan Mulyadi JMV. 2017. Analisis Determinan Persistensi Laba pada Perusahaan Jasa di Bursa Efek Indonesia. Jurnal Riset Akuntansi dan Perpajakan JRAP Vol. 4(1):13-20.

Martani, Siregar, Wardhani, Farahmita, Tanujaya dan Hidayat. 2016. Akuntansi Keuangan Menengah berbasis PSAK. Jilid 2. Jakarta : Salemba Empat.

Martinez, Antonio Lopo, De Souza dan Montemor. 2016. Book Tax Differences, Earnings Persistence, and Tax Planning Before And After The Adoption Of IFRS in Brazil Vol 31 No 3. Advances in Scientific and Applied Accounting vol. 9(3).

Martinez, Antonio Lopo, Filho, dan Anunciação. 2013. Analysis Of The Relationship Between The Components Of Book-Tax Differences And Annual Variations In Earnings And Tax Expenses Of Firms Listed On The Bmf\&Bovespa. Advances in Scientific and Applied Accounting, Sao Paulo V.6 n.3: 397-418.

Panjaitan, Ingrid. 2017. The Effect of Book Tax Differences and Corporate Governance Disclosure on The Quality of Earnings Using Accounting Conservatism as Moderating Variables. International Journal of Business and Law, Vol. 13(1).

Pernamasari, Rieke. 2018. The Effect of Accrual Earnings, Corporate Governance, and Firm Size on Earnings Persistence of 100 Compass Index Companies Listed 2015-2016. Journal of Economic and Sustainable Development Vol 9(10).

Praptitorini, Mirna Dyah dan Rahmawati. 2017. The Effect of Permanent Differences, TemporaryDifferences, LPBTD, LNBTD and Debt Levels on Earnings Persistence. Journal of Applied Manajemen Sciences and Accounting, Vol 8(1).

Rachmawati, N.A. dan Martani, D. 2013. The Effect of Large Positive Abnormal Book Tax Differences on Earnings Persistence. $25^{\text {th }}$ Asian-Pasific Conference on International Accounting Issues.

Rachmawati, N.A. dan Martani, D. 2014. The Effect of Large Positive Abnormal Book Tax Differences on Earnings Persistence. Jurnal Akuntansi dan keuangan Vol 11(2): 120-137.

Resmi, Siti. 2014. Perpajakan Teori dan Kasus. Edisi 8. Jakarta: Salemba Empat.

Saputera, Erwin Nahdi, Norita dan Dillak. 2017. Pengaruh Book Tax Differences dan Aliran Kas Operasi terhadap Persistensi Laba. Jurnal Of Management Vol. 4(1).

Satyawati, Endang dan Palupi. 2017.The Influence of Book Tax Differences on Correlation of Current Earnings, Accruals, and Cash Flow to Future Earnings (Empirical Study on Manufacturing Companie Registered on the Indonesia Stock Exchange in Years 2007-2011). Review of Integrative Business and Economics Research Vol 6, Issue 4.

Waluyo. 2016. The Relationship between Book Tax Differences and Earnings Growthwithin Indonesia Manufacturing Firms. Research Journal of Finance and Accounting Vol 7(18). 
Ekonomi, Keuangan, Investasi dan Syariah (EKUITAS)

Vol 3, No 2, November 2021, Hal 114-123

ISSN 2685-869X (media online)

DOI 10.47065/ekuitas.v3i2.1072

Yulia, Muhairah, Daud, dan Linda. 2018. The Effect of Book-Tax Difference, Accrual Cash Flow and Good Corporate Governance on Earnings Persistence of Manufacturing Companies Listed on IDX in 2010-2014. Broad Research in Accounting, Negotiation, and Distribution Vol 9 Issue 1. 